\title{
ОБЩАЯ ХАРАКТЕРИСТИКА МИКОБИОТЫ РЕДКИХ ДРЕВЕСНЫХ РАСТЕНИЙ АЗЕРБАЙДЖАНА
}

\section{GENERAL CHARACTERISTIC OF THE MYCOBIOTA OF RARE WOODY PLANTS OF AZERBAIJAN}

\section{T. Abbasova}

Summary. In the studies carried out, the species composition of the mycobiota of rare woody plants included in the flora of Azerbaijan was characterized. It was revealed that 58 species of fungi are involved in the formation of the mycobiota of 12 studied woody plants. $53.4 \%$ of the registered fungi belong to the Bazidiomycota division and $46.6 \%$ to the Ascomycota division. Among the registered fungi, fungi-causative agents of dangerous diseases were noted - Fomes fomentarius (white rot), Cercospora microsora (spotting), Microsphaera alphitoides (powdery mildew), etc., included in the pathogenic mycobiota of the studied plants.

Keywords: rare tree species, mycobiota, species composition, frequency of occurrence, pathology.

\author{
Аббасова Тунзала Сабир кызы \\ М.н.с., Центральный Ботанический сад НАНА, Баку \\ sabirqizi1989@gmail.com
}

Аннотация. В проведенных исследованиях был охарактеризован видовой состав микобиоты редких древесных растений, входящих во флору Азербайджана. Было вывялено, что в формировании микобиоты 12 изученных древесных растений участвуют 58 видов грибов. 53,4\% зарегистрированных грибов относятся к отделу Bazidiomycota, а 46,6\% — к отделу Ascomycota. (реди зарегистрированных грибов отмечены грибы-возбудители опасных заболеваний — Fomes fomentarius (белая гниль), Cercospora microsora (пятнистость), Microsphaera alphitoides (мучнистая роса) и др., входящие в патогенную микобиоту исследуемых растений.

Ключевые слова: редкие древесные породы, микобиота, видовой состав, частота встречаемости, патология.
$\mathbf{T}$ ерритория Азербайджанской Республики отличается богатой и разнообразной флорой. Здесь распространено более 4700 видов растений, и по видовому составу флора Азербайджана намного богаче флоры других республик Южного Кавказа. Виды растений, встречающиеся в республике, составляют $66 \%$ от общего числа видов растений, произрастающих на Кавказе[6, 15]. Богатство и разнообразие флоры и растительности страны обусловлено разнообразием её физико-географических и природно-исторических условий, а также сложной историей, сформировавшейся под влиянием далеких флористических ареалов.

Статус растений, распространенных на территории Азербайджанской Республики, также отличается, поскольку эти растения включают как эндемичные, так и реликтовые виды[4]. Редкие растения, отвечающие этой характеристике, были тщательно изучены в ботаническом аспекте, и такие исследования все еще продолжаются. Аналогичная ситуация не наблюдается в микробиологическом аспекте исследования этих растений, особенно тех, которые входят в состав флоры Азербайджана, несмотря на то, что микроорганизмы, в том числе грибы и бактерии, используют растения, а также их мертвые органы в качестве источников питания и вызывают различные патологии, в результате чего ухудшается декоративный вид растений, их биологическая продуктивность, и даже полностью теряется их жизнеспособность[3, 10]. Профилактика данных явлений является актуальной задачей современной биологии, прежде всего микробиологии и микологии.

Поэтому целью представленной работы была характеристика видового состава микробиоты некоторых редких древесных растений, входящих во флору Азербайджана.

\section{Материалы и метолы}

Исследования проводились в разных районах Азербайджана (Астара, Исмаиллы, Ленкорань, Огуз, Габала и др.), и в ходе работы были взяты образцы с редких деревьев, общая характеристика которых представлена ниже[2, 4]:

Alnus subcordata C.A. Mey-Ольха сердцелистная. Это растение рода Ольхи (Alnus L) семейства березовых встречается в Астаринском, Ярдымлинском, Ленкоран- 
ском, Лерикском районах южного региона Азербайджана. Это растение входит в список редких и реликтовых растений нашей страны. Это растение выращенное в окультуренном виде в Ботаническом саду, занесено в «Красную книгу» Азербайджана.

Albizia julibrissin - Акация Дуразз-Ленкораньская. Растение рода Акация (Albizia Durazz) семейства бобовых в основном распространено в Иране, Турции, Японии и Гималаях. В Азербайджане это растение встречается в южном регионе на высоте до 500 м над уровнем моря. Ленкоранская акация входит в список редких и реликтовых растений, а ее природные ресурсы в Азербайджане не так велики.

Carpinus macrocarpa (Willk.) H.P.J. Winkl. -Граб крупноплодный. Это растение относится к роду Граб Carpinus L. (Velas) семейства березовых широко распространено в европейской части России, Малой Азии, Северо-Восточном Иране и др. территориях и являясь нешироко распространенным в Азербайджане, произрастает в Лянкяранских горах. Входит в список редких растений.

Castanea sativa Mill.- Каштан обыкновенный. Каштан обыкновенный - вид дерева рода Каштан (Castanea Hill) семейства арахисовых, широко распространен в Африке, Малой Азии, Италии, Средиземноморье и на Балканах. Каштан обыкновенный в Азербайджане встречается в основном в Загатале, Огузе, Габале, Верхнем Карабахе и на других территориях и считается одним из редких и реликтовых растений Азербайджана, занесен в Красную книгу.

Gleditsia caspia Desf.-Гледичия каспийская. Гледичия каспийская принадлежит роду Гледичия (Gleditsia) семейства бобовых, встречается в южном регионе Азербайджана, природные ресурсы растения скудны и оно считается одним из редких видов растений в нашей стране. Растение выращивается в Ботаническом саду и занесено в «Красную книгу» Азербайджана.

Quercus castaneifolia C.A. May.- Дуб каштанолистный. Это растение, принадлежащее к роду Дуб (Quercus) семейства буковых, широко распространено в Иране. Хотя он встречается в основном в южном регионе (Астара, Ленкорань, Масаллы, Лерик) и на территории Исмаиллы, его ареал не такой большой. Несмотря на то, что растение культивируется, оно считается одним из редких и реликтовых растений Азербайджана и занесено в Красную книгу.

Parrotia persica C.A. Мау.- Железное дерево. Принадлежит роду Парротия (Parrotia C.A. Мay) семейства гамамелисовых, распространен на территории Ирана, где это растение встречается в естественных условиях. В Азербайджане растение, произрастающее в естественных условиях в южном регионе и в Габалинском районе, считается редким и реликтовым растением, занесено в Красную книгу и охраняется в Национальном парке и Государственных заповедниках.

Platanus orientalis L.- Платан восточный. Общий ареал распространения растения, относящегося к роду Платан (Platanus L) семейства Платановых - Средняя Азия, Иран, Турция, страны Средиземноморья и др. В нашей стране распространен на узкой территории Огуза, Габалы, Балакена, Зангилана, Верхнего Карабаха и др. Считается редким и реликтовым растением и занесен в Красную книгу.

Populus hyrcana Grossh.-Тополь гирканский. Относится к роду Тополь (Populus L.) семейства ивовые, в естественной среде имеет общий ареал распространения в Грузии. считается обитания Гирканского тополя, рода тополей. В нашей стране в естественной среде растение распространено в Ленкоране. Растение относится к статусу редких растений.

Pyrus hyrcana Fed.- Груша гирканская. Растение принадлежит к роду Груша (Pyrus L) семейства цветковых. Широко распространено в Иране. Гирканская груша имеет небольшой ареал распространения на территории Азербайджана, принадлежит к редким видам и встречается в Астаре и Ленкоране. Как и другие растения, оно занесено в Красную книгу Азербайджана.

Tilia begoniifolia Stev.- Липа кавказская. Принадлежит к роду Тилия (Tilia L) семейства липовые. Растение распространено в России, Грузии, Турции и Иране. В Азербайджане имеет статус редкого растения и встречается в лесах Большого и Малого Кавказа и Ленкорани. Растение в окультуренном виде выращивают в Ботаническом саду.

Zelkova hyrcana A. Grossh.et.Jarm- Азат Гирканский. Естественный ареал растения, относящегося к роду Азат (Zelkova Spach) семейства вязовых - Иран. В нашей стране естественное распространение отмечается в южном регионе: Астара, Ленкорань, Масаллы, Лерик и т.д. Занесен в Красную книгу Азербайджана со статусом редкого растения.

Отбор образцов этих деревьев, их паспортизация на месте, подготовка к лабораторному анализу, а также лабораторный анализ проводились в соответствии с методами и подходами [5, 9], используемыми в работах различных авторов[8], в первую очередь П.3. Мурадова [7], Кузьмичева и др.[3]. 
Таблица 1. Общая характеристика грибов, зарегистрированных на исследуемых редких деревьях

\begin{tabular}{|c|c|c|c|c|c|}
\hline № & Отделы грибов & $\begin{array}{l}\text { Количество } \\
\text { видов (ед.) }\end{array}$ & $\begin{array}{l}\text { Экотрофическая связь } \\
\text { (\%) }\end{array}$ & $\begin{array}{l}\text { Цвет гнили, } \\
\text { вызываемого } \\
\text { в естественных } \\
\text { условиях (\%) }\end{array}$ & $\begin{array}{l}\text { Отношение к субстрату } \\
\text { (\%) }\end{array}$ \\
\hline 1 & Ascomycota & 24 & $\begin{array}{l}\text { Сапротроф- 5,2 } \\
\text { Биотроф- 5,2 } \\
\text { Политроф-89,6 }\end{array}$ & $\begin{array}{l}\text { Белая - 8,3 } \\
\text { Бурая - 16,7 } \\
\text { Мягкая - 75,0 }\end{array}$ & $\begin{array}{l}\text { Эвритрофы-9,2 } \\
\text { Условный стенотроф-12,5 } \\
\text { Стенотроф- 8,3 }\end{array}$ \\
\hline 2 & Bazidiomycota & 34 & $\begin{array}{l}\text { Сапротроф - 8,8 } \\
\text { Биотроф - 23,5 } \\
\text { Политро } \phi-67,7\end{array}$ & $\begin{array}{l}\text { Белая - 64,8 } \\
\text { Бурая - 20,6 } \\
\text { Мягкая - 14,7 }\end{array}$ & $\begin{array}{l}\text { Эвритроф -94,1 } \\
\text { Условный стенотроф- 5,9 } \\
\text { Стенотроф-0 }\end{array}$ \\
\hline
\end{tabular}

Определение микроорганизмов, распространенных на деревьях, и вызываемых ими заболеваний проводилось согласно известным определителям [1, 11-14].

\section{Полученные результаты} и их обсужление

В результате исследования, начатого в 2017 году, и анализа более 500 образцов, отобранных с 12 древесных пород флоры Азербайджана, выявлено распространение 58 видов грибов, данные о которых обобщенно приведены в таблице 1. Как видно, зарегистрированные грибы характеризуются разнообразием с точки зрения их эко-трофических отношений, их отношения к субстрату и цвета вызываемой в естественных условиях гнили, и это разнообразие сохраняется на уровне отделов. Однако подавляющее большинство как макромицетов, так и микромицетов, зарегистрированных в исследованиях (\% от общего числа грибов), по эколо-трофическим связям принадлежат к политрофам (биотрофность и сапротрофность не несет истинного характера), а по отношению к субстрату являются эвритрофами.

Количественный анализ видов зарегистрированных грибов показал, что в отделе Bazidiomycota роды Fomitopsis (F.annosa, F.officinalis, F.pinicola), Inonotus (I.cuticularis, I.dryophilus, I.dryadeus, I.hispidus) и Phellinus (Ph.igniarus), Ph. pini, Ph. pomaseus, Ph. robustus, Ph. torulosus), а в отделе Ascomycota роды Gloeosporium (G.quercinum, G.tiliae, G.tremulae), Penicillium (P.divergens, P.glaucum, P.puberulum, P.restictum) характеризуются большим количеством видов. Остальные роды (Alternaria, Armillaria, Botrytis, Cercospora, Cladosporium, Colpoma, Cryphonectria, Cytospora, Daedalea, Fusarium, Fomes, Ganoderma, Laetiporus, Microsphaera, Naemospora, Phomopsis, Phyllosticuroticillia, Spuro, Pleurosticilleta, представлены Pleurosticilleminium, Pleurosticilla) в формировании микобиоты исследуемых растений представлены 1-2 видами.
В литературе встречаются данные о распространении в Азербайджане большинства грибов, выявленных в ходе исследований. Однако есть также виды, распространение которых зарегистрировано впервые, они представлены ниже:

1. Naemospora croceola Sacc. (1880) [MB \# 181608] - Гриб входит к микобиоту дуба каштанолистного, и при исследованиях он был обнаружен в образце, взятом с его молодых побегов.

2. . Phyllosticta lacerans Pass., Atti della Reale Accademia dei Lincei. Rendiconti di classe di Scienze Fisiche, Matematiche e Naturale Ser. 4, 4 (2): 65 (1888) [MВ\#213238]. Гриб входит к микобиоту азата гирканского, и при исследованиях он был обнаружен в образце, взятом с его листях.

3. . Penicillium divergens Bainier \& Sartory, Bulletin de la Société Mycologique de France 28: 270 (1912) [MB\#170179]. Гриб, относящийся к анаморфной группе грибов, впервые был обнаружен в образце, взятом из листьев дуба каштанолистного.

Следует отметить, что между грибами и растениями, в том числе деревьями, формируются различные взаимоотношения, одно из которых - паразитизм, и формой проявление этой связи являются различные патологии растений. Существование этих взаимоотношений между грибами, зарегистрированными в исследованиях, и исследуемыми деревьями подтверждено различными исследованиями. По этой причине было сочтено целесообразным охарактеризовать в этом аспекте зарегистрированные грибы, т.е. выявить болезни, вызываемые ими у исследуемых растений. Полученные результаты показали, что зарегистрированные грибы вызывают у исследуемых растений различные заболевания, распространенность которых характеризуется разными количественными показателями. Так, наиболее частым заболеванием исследуемых деревьев является гниль, вызываемая различными видами базидиомицетов, а белую гниль можно обнаружить у всех 12 изученных видов деревьев. Возбудителями этой гнили в основном являются виды родов Armillaria, Fomes 
и Ganoderma, а наиболее высокую степень распространения и опасности гниения имеет гриба $F$. fomentarius. Кроме того, гриб Gaanoderma lipsiciense также может обитать на всех изученных деревьяъ и проявлять патогенную активность.

Следует отметить, что хотя и есть некоторые различия в специфике заболеваний, вызываемых видами разных родов, но в целом зона развития болезни имеет белый цвет.

Болезни буоой и серой гнили также характеризуются относительно высокой распространенностью, и в их развитии участвуют виды, принадлежащие к роду Fomitopsis, Inonotus, Laetiporus, Botrytis и др. Примерно 50-80\% исследованных деревьев относятся к субстратам, которые они заселяют.

Помимо перечисленных, на исследуемых деревьях были зарегистрированы и другие заболевания. Например, корневая гниль у каштанолистного дуба (возбудитель Rosellinia quercina), мучнистая роса (Microsphaera alphitoides), черный немоспоровый некроз (Naemospora croceola), бурая пятнистость (Gloeosporium quercinum), темно-бурая пятнистость у кавказской липы (Cercospora microsora), кремовая пятнистость (Gloeosporium tiliae), серая пятнистость азата гирканского (Phyllosticta lacerans), черный цитоспоровый некроз (Cytospora foetida) у платана восточного и др. Хотя общая распространенность всех этих заболеваний у исследуемых деревьев невысока по сравнению с другими болезнями, следует отметить, что для некоторых видов деревьев они представляют опасность

Хотя очевидно, что большинство возбудителей заболеваний, зарегистрированных в ходе исследований, относятся к грибам, исследованиями были выявлены заболевания, вызванные также и бактериямии. Так бактерии Pseudomonas cerasi и Ps.quercina, также были обнаружены в ходе исследований, и вызываемое ими заболевание обычно называют раком. Однако, по сравнению с грибами заболевания вызыванные бактериями характеризуются низкими показателями как по количеству, так и по степени их распространения.

Таким образом, в результате исследований было выявлено, что редкие виды деревьев, входящие во флору Азербайджана, являются одной из сред обитания микроорганизмов, и особую значимость среди этих микроорганизмов имеют грибы. Так, как по распространенности, так и по количеству вызываемые грибами болезни характеризуются высокими показателями.

\section{ЛИТЕРАТУРА}

1. Бондарцева М.А. Определитель грибов России. Порядок афиллофоровые. СП.: Наука, 1998, вып. 2, 391с.

2. Красная книга Азербайджанской Республики. Редкие и исчезающие виды растений и грибов. Баку: Издательство «Запад-Восток», 2013, 676с.

3. Кузьмичев Е.П., Соколова Э.С., Мозолевская Е.Г. Болезни древесных растений: справочник. М.: ВНИИЛМ, 2004, 120 с

4. Мамедов Т.С., Искендер Э.0., Талыбов Т.Г. Редкие древесные и кустарниковые растения Азербайджана. Учебник. Баку: Изд. Наука, $2014,380 с$.

5. Методы экспериментальной микологии/Под. ред. Билай В.И. -Киев: Наукова думка, —1982, —500с

6. Mehdiyeva N.P. Azərbaycanın dərman florasının biomüxtəlifliyi. Bakı: "Letterpress”, 2011, $186 \mathrm{s.}$

7. Мурадов П.З. Изменение активности гидролаз и оксидаз в процессе конверсии растительных отходов. Автореф. дис. доктора биол. наук. Баку, 2004, $48 \mathrm{c}$.

8. Мухин, В.А. Полевой определитель трутовых грибов. Екатеринбург, 1997, 104 с.

9. Нетрусов А.И., Егорова М.А., Захарчук Л.М. и др. Практикум по микробиологии. М.: Издательский центр «Академия», 2005, 一608с.

10. Попкова К.В., Шкаликов В.А., Стройков Ю.М. и др. Общая фитопатология: учебник для вузов. М.: Дрофа, 2005, 445 с.

11. Саттон Д., Фотергилл А., Риналди М. Определитель патогенных и условно патогенных грибов. М.: Мир, 2001, $486 c$.

12. Horst K.R. Westcott's Plant Disease Handbook. Eighth Edition. New York: Springer Science, 2013, 826 c.

13. Kirk P.M.et al. Ainsworti and Bisbys Dictionary of the fungi. 9th edd. CAB International, 2001, 655 p.

( Аббасова Тунзала Сабир кызы ( sabirqizi1989@gmail.com ).

Журнал «Современная наука: актуальные проблемы теории и практики» 